\title{
Learning Mathematical Modeling: Analysis of Mathematical Reasoning Skills of Junior High School Students Through a Visual-Formed Problem
}

\author{
Intan Sahara ${ }^{1}$ Darmawijoyo ${ }^{2, *}$ Yusuf Hartono ${ }^{3}$ \\ 1,2,3 Mathematics Education Department, Sriwijaya University, Indralaya, South Sumatera, Indonesia \\ "Corresponding author. Email: darmawijoyo@unsri.ac.id
}

\begin{abstract}
This research aims to describe secondary school students' mathematical reasoning skills through visual-formed problem under a mathematical modeling framework. This research involved 19 seventh grade students of SMPN 6 Indralaya Utara. Data were collected through a test and interview. Result show that a visual-formed problem under a mathematical modeling framework contributed to students' mathematical reasoning skills.
\end{abstract}

Keywords: Mathematical Reasoning Skills, Visual-formed Problem, Mathematical Modeling.

\section{INTRODUCTION}

Reasoning as one of the cognitive components of humans is used to understand science and natural phenomena. Learning indeed plays an important role in developing this aspect. Therefore, human civilization becomes more advanced. Mathematics as science based on the deductive approach, needs reasoning as the main tool to develop understanding both of the mathematics itself and its application. Reasoning in the current mathematics curriculum of Junior high school in Indonesia is one of the competencies [1]. According to [2], mathematical reasoning is the key element in mathematics and the center of attention for mathematical learning in schools.

It is expected that mathematical learning in schools, according to the 2013 curriculum, will produce students acquiring this mathematical reasoning skill. However, there is a strong indication that the learning has yet focused on this the desired target. For example, PISA for mathematics in 2018 showed that only $1 \%$ of students were able to do 5 and 6 level mathematic questions [3]. PISA questions for these two levels are mathematical problems that need reasoning.

Some research discussing PISA result stated that difficulties experienced by Indonesian students in solving high-level PISA questions including difficulties in: (1) solving mathematical problems; (2) understanding problems or questions; (3) converting a real-world problem into a mathematical problem; (4) drawing conclusion based on solutions given [4]. The inability of Indonesian students to solve high-level PISA questions was because students still cannot understand context-based questions $[5,6]$. Consequently, this context-based learning, especially context relating to students' activities in their environment, should be considered as an object of learning material. One of the teaching and learning approaches being most likely appropriate to context based learning is mathematical modeling.

According to [7], mathematical modeling has an important role in developing elementary students' mathematical reasoning skills in Singapore. Mathematical modeling plays an important role in establishing a logical connection [8], where logical thinking is part of the reasoning [9]. Mathematical modeling includes dealing with problems, making problems, reasoning, and mathematical structure to change a situation, so it can be considered that reasoning is part of mathematical modeling [10].

Research discussing mathematical reasoning skills using visual-formed problems was rarely found. That is why the visual-formed problem was used in this research because visualization has an important role in solving a mathematical problem, helping students explore mathematical questions, and making mathematical concepts more meaningful [11, 12]. Research performed by [13] shows that students' performance is better when they solve visual problems compared to ordinary text questions. Therefore, the 
researcher explored junior high school students' mathematical reasoning skills by implementing a visualformed problem using mathematical modeling learning. Through a visual-formed problem, the researcher described the mathematical reasoning skill of studentgrade VII. 2 of SMPN 6 Indralaya Utara.

\section{RESEARCH METHOD}

This was descriptive research with a qualitative approach. This research aims to describe and provide an overview of junior high school students' mathematical reasoning skills through a visual-formed problem based on the inverse proportion material. Subjects in this research were 19 students grade VII.2 of SMPN 6 Indralaya Utara. This research was performed in the even semester of the 2019/2020 school year.

Visual questions were used in this research during mathematical modeling learning. The following is the visual-formed problem used in this research.

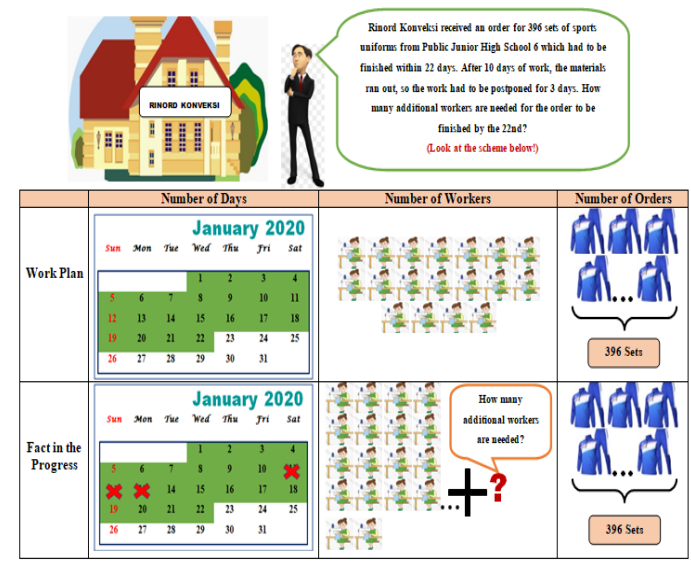

Figure 1 Visual-formed Problem.

Figure 1 above is a visual-formed problem used in this research during the implementation of mathematical modeling learning. The visual-formed problem was the modified problem from National Examination questions for junior high school about the inverse proportion. The national examination problem was developed into a mathematical modeling problem in the form of text by adding context to sports uniform order. After that, the text was developed into visual form by adding a picture and reducing the use of words without changing the problem's meaning.

Meanwhile, post-test problems used in this research were mathematic narrative questions without pictures in the inverse proportion material aiming to observe students' mathematical reasoning skills in solving daily life problems related to the inverse proportion material. In this post-test question, the context used was relating to the construction of a hospital building. The post-test question used in this research can be seen in the following figure 2 .

POST-IEST
1. To renovate a hospital building, a contractor needs 24 workers in 25 days. It
tumed out that 4 workers had resigned. Due to the difficulty of finding
replacements for the four workers, the contractor decided to continue to
employ the remaining workers and increase the working time.How many
additional days are needed for the hospital building renovation to be finished?

Figure 2 Post-Test Question.

The followings are the details of activities carried out in this research.

\subsection{First Meeting}

In the first meeting, the activity carried out was pretest. The pre-test aimed to observe students' initial competence relating to the inverse proportion that they had already learned before, and the result of this pre-test was used to form student discussion groups. These discussion groups were then implemented in mathematical modeling learning.

\subsection{Second Meeting}

In the second meeting, mathematical modeling learning using visual questions was implemented. The mathematical modeling learning using visual questions was carried out in one meeting. Students worked within the groups where the teacher guided them to work. Each group was given a visual-formed problem containing a table to help students to solve the problem. The visualformed problem given to each group was equipped with Student Worksheets containing questions guiding students to solve the problem. After working on the visual-formed problem, the teacher chose two groups to present their results in front of the class.

\subsection{Third Meeting}

A post-test was carried out in the third meeting to identify students' mathematical reasoning skills in solving daily life problems relating to the inverse proportion. Indicators for mathematical reasoning skill and scoring guidelines for post-test in this research is as follow. 
Table 1. Indicator for mathematical reasoning skill

\begin{tabular}{|c|c|}
\hline $\begin{array}{l}\text { Indicator for } \\
\text { mathematical } \\
\text { reasoning skill } \\
\end{array}$ & Descriptors \\
\hline $\begin{array}{l}\text { Presenting written } \\
\text { mathematical } \\
\text { questions }\end{array}$ & $\begin{array}{l}\text { 1. Identifying information } \\
\text { needed to solve problems } \\
\text { and write it down in the } \\
\text { answer sheets }\end{array}$ \\
\hline \multirow{3}{*}{$\begin{array}{l}\text { Performing } \\
\text { mathematical } \\
\text { manipulation }\end{array}$} & $\begin{array}{l}\text { 2. Formulating problems } \\
\text { questions in the problem }\end{array}$ \\
\hline & $\begin{array}{l}\text { 1. Making a mathematical } \\
\text { model based on } \\
\text { information found in the } \\
\text { problem }\end{array}$ \\
\hline & 2. Performing mathematical \\
\hline
\end{tabular}

\begin{tabular}{ll}
\hline & $\begin{array}{l}\text { calculations accurately to } \\
\text { solve the problem }\end{array}$ \\
$\begin{array}{l}\text { Drawing logical } \\
\text { conclusions }\end{array}$ & $\begin{array}{l}\text { Stating the solution } \\
\text { obtained into sentences } \\
\text { according to the real-life } \\
\text { problem given }\end{array}$ \\
\hline
\end{tabular}

Table 2. Scoring guideline for post-test

\begin{tabular}{|c|c|c|c|}
\hline Indicators & & Answer criteria & Score \\
\hline \multirow[t]{8}{*}{$\begin{array}{l}\text { Presenting written } \\
\text { mathematical } \\
\text { questions }\end{array}$} & $\begin{array}{l}\text { Identifying information needed } \\
\text { to solve problems and write it } \\
\text { down in the answer sheets }\end{array}$ & $\begin{array}{l}\text { Identifying information needed to solve } \\
\text { problems and write it down in the answer } \\
\text { sheets correctly and completely }\end{array}$ & 3 \\
\hline & & $\begin{array}{l}\text { Identifying information needed to solve } \\
\text { problems and write it down in the answer } \\
\text { sheets correctly, but not completely }\end{array}$ & 2 \\
\hline & & $\begin{array}{l}\text { Identifying the information needed to solve } \\
\text { problems and write it down in the answer } \\
\text { sheets, but the answer is wrong. }\end{array}$ & 1 \\
\hline & & No response and answer & 0 \\
\hline & $\begin{array}{l}\text { Formulating problems questions } \\
\text { in the problem }\end{array}$ & $\begin{array}{l}\text { Formulating problems stated in the problem } \\
\text { correctly and completely. }\end{array}$ & 3 \\
\hline & & $\begin{array}{l}\text { Formulating problems stated in the problem } \\
\text { correctly but not completely }\end{array}$ & 2 \\
\hline & & $\begin{array}{l}\text { Formulating problems stated in the problem, } \\
\text { but still wrong }\end{array}$ & 1 \\
\hline & & No response and answer & 0 \\
\hline \multirow[t]{8}{*}{$\begin{array}{l}\text { Performing } \\
\text { mathematical } \\
\text { manipulation }\end{array}$} & $\begin{array}{l}\text { Making a mathematical model } \\
\text { based on information found in } \\
\text { the problem }\end{array}$ & $\begin{array}{l}\text { Making a mathematical model based on } \\
\text { information found in the problem correctly and } \\
\text { completely }\end{array}$ & 3 \\
\hline & & $\begin{array}{l}\text { Making a mathematical model based on } \\
\text { information found in the problem correctly but } \\
\text { not completely }\end{array}$ & 2 \\
\hline & & $\begin{array}{c}\text { Making a mathematical model based on } \\
\text { information found in the problem, but still } \\
\text { wrong }\end{array}$ & 1 \\
\hline & & No response and answer & 0 \\
\hline & $\begin{array}{l}\text { Performing mathematical } \\
\text { calculations accurately to solve } \\
\text { the problem }\end{array}$ & $\begin{array}{l}\text { Performing mathematical calculation to solve } \\
\text { the problem correctly and completely. }\end{array}$ & 3 \\
\hline & & $\begin{array}{l}\text { Performing mathematical calculation to solve } \\
\text { the problem correctly but not completely }\end{array}$ & 2 \\
\hline & & $\begin{array}{l}\text { Performing mathematical calculation to solve } \\
\text { the problem, but still wrong }\end{array}$ & 1 \\
\hline & & No response and answer & 0 \\
\hline
\end{tabular}




\begin{tabular}{|c|c|c|c|}
\hline \multirow[t]{4}{*}{$\begin{array}{l}\text { Drawing logical } \\
\text { conclusions }\end{array}$} & $\begin{array}{l}\text { Stating the solution obtained } \\
\text { into sentences according to the } \\
\text { real-life problem given }\end{array}$ & $\begin{array}{l}\text { Stating the solution obtained into sentences } \\
\text { according to the real-life problem given } \\
\text { correctly and completely }\end{array}$ & 3 \\
\hline & & $\begin{array}{l}\text { Stating the solution obtained into sentences } \\
\text { according to the real-life problem given } \\
\text { correctly but not completely }\end{array}$ & 2 \\
\hline & & $\begin{array}{l}\text { Stating the solution obtained into sentences } \\
\text { according to the real-life problem given, but } \\
\text { still wrong }\end{array}$ & 1 \\
\hline & & No response and answer & 0 \\
\hline
\end{tabular}

Data in this research were collected through a test and an interview. The test in this research was a posttest consisting of one description item question about inverse proportion. The interview performed in this research aimed to observe students' mathematical reasoning skills and find how students' points of view on problems relating to daily life and visual problems were given. Data that had been collected were analyzed. For post-test questions, students' answers to the post-test question were corrected and scored a rubric. The total score obtained was then used to determine the final score to be obtained by students. After that, students' mathematical reasoning skill was categorized based on the score obtained. Meanwhile, data obtained from the interview was in the form of recording, which was converted into written form by referring to good and understandable language.

\section{RESULT AND DISCUSSION}

\subsection{Result}

Following is the table of students' mathematical reasoning skill categorization.

Table 3 Categorization of students' mathematical reasoning skill.

\begin{tabular}{cccc}
\hline $\begin{array}{c}\text { The Range } \\
\text { of Post-Test } \\
\text { Score }\end{array}$ & Frequency & $\begin{array}{c}\text { Percenta- } \\
\text { ge }\end{array}$ & Category \\
\hline $80 \leq$ Score $\leq 100$ & 3 & $15,8 \%$ & Very Good \\
$60 \leq$ Score $<80$ & 2 & $10,5 \%$ & Good \\
$40 \leq$ Score $<60$ & 10 & $52,6 \%$ & Acceptable \\
$20 \leq$ Score $<40$ & 4 & $21,1 \%$ & Poor \\
$0 \leq$ Score $<20$ & 0 & $0 \%$ & Very Poor \\
Total & 19 & & \\
\hline
\end{tabular}

The following table shows the percentage of occurrence of each indicator for mathematical reasoning skill.
Table 4 Percentage of occurrence of each indicator for mathematical reasoning skill.

\begin{tabular}{lcl}
\hline \multicolumn{3}{c}{ Indicator for Mathematical Reasoning Skill } \\
\hline $\begin{array}{l}\text { Presenting } \\
\text { written } \\
\text { mathematical } \\
\text { questions }\end{array}$ & $\begin{array}{l}\text { Performing } \\
\text { mathematical } \\
\text { manipulation }\end{array}$ & $\begin{array}{l}\text { Drawing } \\
\text { logical } \\
\text { conclusions }\end{array}$ \\
& & \\
$74,6 \%$ & $41,2 \%$ & $22,8 \%$ \\
\hline
\end{tabular}

Based on the post-test result, the researcher chose two students as a subject for an interview related to mathematical reasoning skills and students' point of view on visual problems and mathematical problems related to daily life. The two students were YP and $\mathrm{CPO}$, who were categorized in very good mathematical reasoning skills. The researcher chose them because they had good communication skills. The following is the answers to the two subjects.

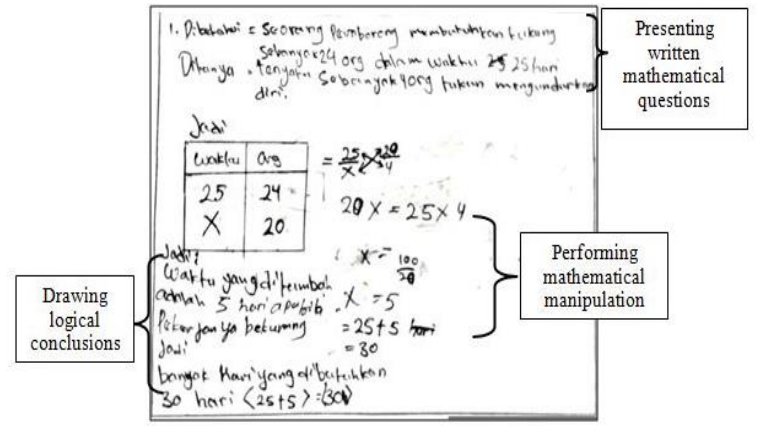

Figure 3 The answers to YP subject.

Based on figure 3 above, in the indicator for presenting written mathematical questions, YP wrote information needed to solve the problem, but it was still incomplete, and YP was not able to formulate the problem questioned in the problem correctly. In contrast, in the indicator for performing mathematical manipulation, YP was able to make a mathematical model according to the problem given correctly, which was $20 \mathrm{x}=25 \times 4$, and YP was able to perform mathematical calculation correctly to solve the problem, 
so YP was able to conclude the solution obtained that was adjusted with the real-life problem.

YP was one of the active students during the discussion in mathematical modeling learning activities. In solving the post-test question, YP observed the number of work that was not done by the resigned worker and divided it with the number of the remaining worker. YP's completion method was almost the same as the complete method for the visual-formed problem that had been given previously, which was in solving the visual-formed problem when the students observed the number of clothes order that was not done during the day off and divided it with the number of remaining days. Post-test question and visual-formed problem given was the value turned comparison material having the same type. Here is the complete strategy on the last stage used in the visual-formed problem working sheet.

$$
\begin{aligned}
& \text { The mumber of orders for clothes that were not done due to holidays }=3 \times 18=54 \\
& \text { Remaining days }=22-13=9 \\
& \text { Additional workers }=\frac{\text { The mumber of orders for clothes that were not done due to holidays }}{\text { remaining days }}=\frac{54}{9}
\end{aligned}
$$

Based on the explanation above, it can be found that mathematical modeling learning used a visual-formed problem that had been carried out to contribute to the YP mathematical reasoning skill. Here is the interview result carried out with YP:

$\mathrm{R}$ : Here, I would like to ask you about the lesson we have learned in the previous meeting. What do you think? Does the math lesson I taught yesterday required you to memorize the formula? If it is yes, what formula is it?

YP : Yes, math formula such as division, subtraction, multiplication

$\mathrm{R}$ : So, it means you only use division, subtraction, and multiplication, right. Ok. Next, what do you think? Does the math lesson I taught you yesterday made you feel happy to learn in class? Why?

YP : Yes, it was so fun because I could learn while playing

$\mathrm{R}$ : What do you think? Did the math lesson I teach you were more interesting than math in the textbook?

YP : Yes, it was interesting because it increased our knowledge.

$\mathrm{R}$ : Do you want math to be taught as I taught you yesterday? Why?

YP : Yes, because math becomes easy.
$\mathrm{R}$ : Did the picture or poster provided in the math lesson yesterday helped you to solve the problems?

YP : Yes, it did. I could calculate and find the answer easily.

Based on the interview, it was found that mathematical modeling learning using a visual-formed problem helped YP to learn in class happily, and the lesson became more interesting. YP also considered that pictures and table provided helped YP to calculate and find the answer or solution for the problem

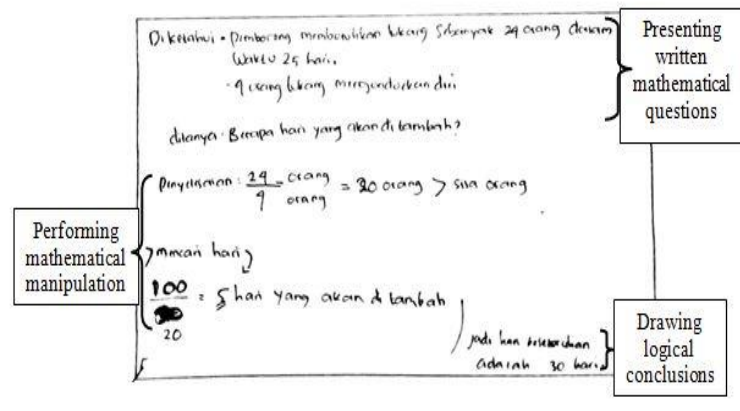

Figure 4 The Answer to CPO Subject.

Based on Figure 4 above, in the indicator for presenting written mathematical questions, CPO was able to write information needed and formulate the problem questioned correctly. In the indicator for performing mathematical manipulation, CPO was able to make a mathematical model based on the problem, but it was still incomplete. CPO was able to perform mathematical calculations correctly to solve the problem. However, CPO was able to conclude the solution obtained according to the real-life problem correctly.

CPO was also one of the active students during the discussion in mathematical modeling learning activities. In solving the post-test question, the strategy or steps being used to solve the problem was almost the same as the step used by YP. Observing the volume of remaining work, by dividing the work volume by the number of work that could be done by one worker. In solving the inverse proportion problem, CPO also only used simple mathematical operations such as multiplication, subtraction, and division, not only stuck to a particular formula. Therefore, it could be found that mathematical modeling learning using a visual-formed problem contributed to CPO's mathematical reasoning skill in solving a similar inverse proportion problem.

Here is the interview result carried out with CPO.

$\mathrm{R}$ : I would like to ask you a question about the lesson we have done in the previous meeting, particularly in using the table. Do you think that the math lesson I taught yesterday required a formula or not? 
CPO: not really. We just needed division, subtraction, addition, or multiplication.

$\mathrm{R}$ : next, did you think that the math lesson I taught yesterday makes you feel happy to learn in class? Were you happy if I also provided working steps and the table in addition to the problem?

CPO: yes, because it became easier.

$\mathrm{R}$ : What did you think? Did the math lesson I taught you were more interesting than math in the book?

CPO : Yes, it was interesting because it was simple.

R : Do you think we need to add lesson hours for math if math is taught like what I taught? For example, providing problems with pictures, not only text.

CPO : yes, because I am not really good at math

$\mathrm{R}$ : so did you understand more than others if the learning was carried out like yesterday?

CPO : yes

$\mathrm{R}$ : Did the picture or poster in the math lesson yesterday help you understand what you need to do and find?

CPO: yes, for example, when I was given table 1and steps to fill in, I could simply look for the answer from it.

Based on the result of the interview above, it could be found that mathematical modeling learning using a visual-formed problem that had been done helped CPO to be happier to learn in class because the lesson became fun and easy to understand. CPO also considered that pictures and table provided helped CPO to calculate and find the answer or solution for the problem, and the problem-solution did not only stuck to in particular formula, simply using simple mathematical operation.

\subsection{Discussion}

This research discussed the mathematical reasoning skill of students grades VII/.2 of SMPN 6 Indralaya Utara. It was shown by the result of students' post-test in which mathematical modeling learning using visual problem had been performed previously. Based on the research result, it was found that mathematical modeling learning using a visual-formed problem contributed to the students' mathematical reasoning skills. It was indicated by the percentage achievement of each indicator for mathematical reasoning that was good enough, especially in indicators for presenting written mathematical statements and indicators for performing mathematical manipulation. Besides, in indicator for performing mathematical manipulation, some students were able to do a mathematical calculation in the posttest by implementing strategy when solving the visual- formed problem. Therefore, students did not stick to a particular formula. They could simply use simple mathematical operations such as multiplication, division, subtraction, and addition. This achievement was great, given that mathematical modeling learning was only implemented once, and the students were able to meet the indicator for mathematical reasoning skills quite well.

The students also considered that the visual-formed problem was more interesting and could be understood easier than the problem in the textbooks presented in only text form. This result was in line with the research result conducted by [13], stating that students' performance was better when they solved a visualformed problem compared to text problems. They also became more interested in following learning activities because it was fun and easy. It was also caused by the provision of tables and students worksheets containing questions leading students to be able to solve the problem given.

\section{CONCLUSION}

The given visual-formed problem contributed to students' mathematical reasoning skills. The posters or tables provided can help students solve the problems. Visual-formed problems helped students interested in the learning mathematics. Visual problems were more attractive and easier to understand than problems in mathematics textbooks. Besides, a visual-formed problem that had been implemented was considered useful in everyday life because it related to real-life problems that were close to students. Students also wanted mathematics learning using a visual-formed problem to be taught more often in class.

\section{ACKNOWLEDGMENTS}

The researcher would like to thank to Mrs. Elika Kurniadi, M. Sc., and Mrs. Dwi Ratna, S. Pd. as validators who had contributed in validating instruments used in this research.

\section{REFERENCES}

[1] Kemendikbud. (2016). Peraturan Menteri Pendidikan dan Kebudayaan Republik Indonesia Nomor 21 Tahun 2016. Jakarta: Kemendikbud.

[2] Brodie, K. (2009). Teaching mathematical reasoning in secondary school classrooms (Vol. 775). Springer Science \& Business Media. Tersedia https://books.google.co.id/books?id=H9bBTG1uY ToC\&pg=PA76\&dq=Teaching+mathematical+reas oning+ini+secondary+school+classroom\&hl=id\&s

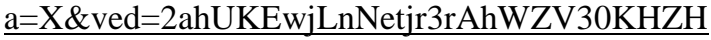
NBaUQ6AEwAHoECAAQAQ\#v=onepage \&q=Te 
aching $\% 20$ mathematical\%20reasoning $\% 20 \mathrm{ini} \% 20$ secondary $\% 20$ school $\% 20$ classroom $\& \mathrm{f}=$ false diakses pada 25 Mei 2020.

[3] OECD. (2019). PISA Results from PISA 2018. https://www.oecd.org/pisa/publications/PISA2018_ CN_IDN.pdf. diakses pada 25 Mei 2020.

[4] Simalango, M. M., Darmawijoyo, \& Aisyah, N. (2018). Kesulitan siswa dalam menyelesaikan soalsoal pisa pada konten change and relationship level 4, 5, dan 6 di SMP N 1 Indralaya. Jurnal Pendidikan Matematika, 12(1), 43-58.

[5] Kamaliyah, Zulkardi, \& Darmawijoyo. (2013). Developing the sixth level of PISA-like mathematics problems for secondary school students. Indonesian Mathematical Society Journal on Mathematics Education, 4(1), 9-28.

[6] Wijaya, A. (2015). Kesalahan Siswa dalam Memilah Data Relevan pada Soal Matematika Berbasis Konteks. Prosiding Seminar Nasional Matematika dan Pendidikan Matematika UMS. Hal. 461-469.

[7] Eric, C. C. M. (2009). Mathematical Modelling as Problem Solving for Children in the Singapore Mathematics Classroom. Journal of Science and Mathematics Education in Southeast Asia, 32(1), 36-61

[8] Ferreira, D. H. L., \& Jacobini, O. R. (2009). Mathematical modelling: From classroom to the real world. Mahtematical applications and modelling in the teaching and learning of mathematics. IMFUFA tekst, (461), 35-46.
[9] Utari, T., \& Hartono, H. (2019). Muatan penalaran dan pembuktian matematis pada buku teks matematika SMA kelas X Kurikulum 2013. Jurnal Riset Pendidikan Matematika, 6(1), 1-13.

[10] Confrey, J., \& Maloney, A. (2007). A theory of mathematical modelling in technological settings. In Modelling and applications in mathematics education (pp. 57-68). Springer, Boston, MA.

[11] Makina, A., \& Wessels, D. (2009). The role of visualization in data handling in Grade 9 within a problem-centred context. Pythagoras, 2009(69), 56-68.

[12] Utomo, E. S., (2015). Proses visualisasi siswa bergaya tactile dalam menyelesaikan soal pada aspek meng-generation. Seminar Nasional Matematika dan Pendidikan Matematika UNY. Hal. 475-480.

[13] Hoogland, C. P. (2016). Images of numeracy: investigating the effects of visual representations of problem situations in contextual mathematical problem solving. Technische Universiteit Eindhoven. 